This is an electronic reprint of the original article. This reprint may differ from the original in pagination and typographic detail.

Author(s): Ihalainen, Pasi

Title: $\quad$ European Parliamentary Experiences from a Conceptual Historical Perspective

Year: $\quad 2016$

Version:

Please cite the original version:

Ihalainen, P. (2016). European Parliamentary Experiences from a Conceptual Historical Perspective. In P. Ihalainen, C. Ilie, \& K. Palonen (Eds.), Parliament and Parliamentarism : A Comparative History of a European Concept (pp. 19-31). Berghahn books. European Conceptual History, 1.

All material supplied via JYX is protected by copyright and other intellectual property rights, and duplication or sale of all or part of any of the repository collections is not permitted, except that material may be duplicated by you for your research use or educational purposes in electronic or print form. You must obtain permission for any other use. Electronic or print copies may not be offered, whether for sale or otherwise to anyone who is not an authorised user. 
Chapter 1

\section{European Parliamentary Experiences from a Conceptual Historical Perspective}

\section{Pasi Ihalainen}

The chapters in Part I of this volume (Chapters 1 to 7) aim at a deeper historical understanding of the formation of parliamentarism as a key concept in modern European political cultures. Their starting point is that the common European tradition of parliamentary political cultures can be better understood through comparative diachronic analyses of parliamentary experiences and the uses of the vocabulary of parliamentarism in political argumentation in various national contexts and in various historical periods since the French Revolution. We aim at estimating the degree of parliamentarism in various historical contexts from the contemporaries’ point of view.

The plural form 'parliamentarisms' is used here because a singular form would be oversimplifying for the purposes of historical analysis, given the essentially national character of most parliaments, parliamentary experiences and applications of parliamentarism (cf. Ihalainen, Ilie and Palonen and Chapter 13 in this volume, where a different perspective to the history of parliament by means of the concept of ideal type is presented). Even if our cooperative comparative history in this part aims at generalizations about European parliamentary history based on several contextualized case studies focusing on national contexts, it is important to keep in mind the specificities of various national developments and the versions of 'parliament' and 'parliamentarism' experienced in various times and places. From the point of view of empirically rather than theoretically oriented conceptual history, parliamentarism is not a stable, definable and teleological phenomenon, but rather 
represents interconnected long-term and multisited discursive processes characterized by contestation. These processes have gradually led to the phenomenon we call parliamentarism today - though the political concept still remains contested and varied in meaning.

Historians - aware of the often unique nature of historical developments and of the context-related meanings of concepts as used in particular arguments in past political discourses - remain suspicious of excessive abstractions and attempts to formulate universal concepts (Haupt and Kocka 2004: 24-26). Hence, they also remain cautious when making generalizations about the history of parliamentarism. Educated and working within the paradigms of national history, they have usually studied the history of one parliamentary institution and may remain unwilling to compare it with others. Given the individualistic traditions of historiography, it is far from easy to integrate the research work and interpretations of even two historians dealing with the same parliament - let alone the analyses of two or more national representative institutions. The assumption of the exceptionalism of every national parliament has been a major hindrance to writing a joint European history of parliamentarisms thus far. Generalizations at the European level need to be based on national cases, to be sure, but it is timely to say something more about the longterm conceptual history of European parliamentarisms as well. Parliamentary history seems, indeed, to be moving more generally towards comparative studies - and hopefully also towards transnational parliamentary history (te Velde 2006; Ihalainen 2013a; Ihalainen and Saarinen 2014; the problems of generalizations and the potential, but in many ways limited, transnational influence of parliamentary models will also be discussed in a future volume on 'The Ideal Parliament', based on a EuParl.net conference held in The Hague in 2013.) Even if empirically oriented conceptual history cannot be based on any supposedly universal concept of parliamentarism, the ideal typical approach in the theoretical part (Part III) of this work has encouraged us to formulate initial theses on parliamentarisms, the 
validity of which has then been tested in various national contexts. We do not apply any structural explanations of parliamentarism often favoured in earlier studies, especially in the field of law, or focus on parliamentary culture or communication in general as more recent parliamentary history in several countries has done, but distinctly focus on the linguistic aspects of past experiences of parliamentarisms. We aim at what Quentin Skinner has characterized as ‘seeing things their way’ (Skinner 2002: vii) - i.e., locating debates among parliamentarians and other participants in discourses concerning the key features of parliament in their proper intellectual and discursive contexts in order to conclude exactly what the speakers were doing in putting forward a certain argument that defined parliament or some of its key features in a particular way. Such a social constructivist point of departure emphasizes an awareness of the essentially contingent nature of the historical development of European representative institutions. However, it needs to be pointed out that parliamentary history as practised by many of the leading experts contributing to Part I has been institutional history and that these authors have been persuaded by the current editor to include conceptual aspects in their analyses. The intention has been to build on existing scholarship on parliaments as institutions and to create a bridge between more conventional parliamentary history and the linguistically conscious approaches used in this volume.

The fact that most present-day European political systems are based on parliamentary democracy should not allow us to presume that this state of affairs is somehow an unavoidable outcome of the development of the last two or three centuries, or that parliamentarisms are now finalized or established. Parliamentarisms should rather be seen as both diachronic and synchronic, discursive and competitive processes with transnational dimensions that have taken place in different times and places and also simultaneously in interconnected contexts: a variety of politicians and theorists have conceptualized parliament, constructing, reproducing and contesting parliamentarisms in interaction with each other and 
the discursive political process. Competing understandings of parliamentarisms can be seen in the conceptual struggles that are to be found in the primary sources (Skinner 2002: 125, 176-77; Halonen, Ihalainen and Saarinen 2014; Ihalainen and Saarinen 2014).

One way to avoid the application of teleologies and anachronistic terms and interpretations to parliamentary history - in other words, of writing a traditional 'Whiggish' history of the success story of parliamentarism - is to critically estimate in each national case when the past contributors to the debate actually started to use the concept of parliamentarism and related vocabulary - i.e., when they started to talk about representation, sovereignty, responsibility and deliberation in various national languages. Instead of identifying the exact timings of some 'breakthroughs' in national discourses on parliamentarism, however, our goal is to demonstrate general European trends, to compare the pace of change in various national contexts and to estimate influences and transfers between the national systems of parliamentarism. While this general history of the European concept of parliamentarism(s) is constituted by the separate histories of several essentially national institutions, these histories have been interconnected in multiple ways through often tendentious cross references and comparisons in parliamentary discourse and by the selective adaptation of parliamentary models borrowed from other countries.

The history part comprises six national or regional (combining the Low Countries and Scandinavia) case studies of discursive processes that have defined parliamentarisms in some formative historical periods. These cases demonstrate how the initial thesis of parliamentarisms being constituted by representation, sovereignty, responsibility and deliberation seems to work in various national contexts, and they reveal which alternative converging or diverging themes and concepts have appeared in the historical debate on parliamentarisms. 


\section{Comparative and Transnational History on the Basis of National Case Studies}

The comparisons presented here are based on contextualized nation-state-centred studies that provide representative examples of some major trends in the history of European parliamentary experiences. This approach admittedly represents a more traditional way of writing comparative history through collected works on national cases, rather than a project in which the same team explores exactly the same extensive comparative material transnationally. When national cases are analysed separately by individual authors there exists the risk of semantic confusion. We have tried to avoid this by focusing systematically on the features of parliamentarisms defined by the initial thesis of this volume and by discussing the preliminary results based on parallel sources, in a series of workshops and in the course of the editing process. The national cases represent long-term macro-level surveys rather than detailed micro analyses. The explored cases build on a combination of previous research and the use of extensive corpora of parliamentary debates, making it possible to point to specific features in national histories of parliamentary experiences and draw conclusions on the extent and limits of transnational elements of parliamentarisms.

The national cases discussed include the rather unique institution of the English/British parliament between the English and the French Revolutions. The development of the Westminster system is certainly the best-known case internationally, but it has not necessarily provided any dominant model for the formation of parliamentary government in the rest of Europe. British historians themselves have tended to emphasize the exceptional nature of the British form of parliamentarism and its linkage to their particular political culture (see Chapter 9 for the pre-revolutionary period). However, a conceptual analysis of the formation of the seventeenth- and eighteenth-century British conceptions of parliament, placed in a chronology of other parliamentarisms, helps to relate this exceptional institution to a broader European pattern. 
The French version of parliamentarism has since the Revolution of 1789 offered an alternative to the British model, even if it has also adopted elements of the Westminster model. A further key national case of parliamentarism is provided by Germany as a relative latecomer. Germany is a country where the contestation of parliamentarism reached particularly high levels and many problems of parliamentarism were concretely felt. Turns in the history of German parliamentarism have, furthermore, also affected other latecomers in Northern and Eastern European countries.

Elsewhere in this volume, the formation of parliamentarisms in Spain, Italy and Central and Eastern Europe are discussed from an historical perspective that is relevant for this part of the book as well. In the rest of the historically oriented chapters we have chosen to focus, side by side with the three European great powers, on three comparisons of national cases that reveal interesting contrasts between culturally related smaller countries or between Western and Eastern European understandings of parliamentarism: the Low Countries, Scandinavia and Russia. The Netherlands and Belgium have experienced two varieties of parliamentarism, which, while interrelated through language, historical experiences and their selective application or rejection of foreign (mainly British and French) models have yet been interestingly different in terms of political culture. The Belgian case has also provided models for other parliamentary reformists to follow. Scandinavian histories of parliamentarism, largely unknown outside the Nordic countries despite their considerable length, deserve attention because of their historical originality and the centrality of the tradition of representative government in the formation of specifically Nordic political cultures. Russia, finally, has conventionally appeared as ‘the other' in European political history, and even more so in parliamentary history. It is important to understand what kinds of differing meanings the concepts of parliamentarism have received in Russian political discourse in connection with early and late twentieth-century attempts to introduce elements of 
parliamentarism to Russia. Such a contrast, if anything, reflects the national nature of parliamentarism in the wider European context and helps to relativize any strictly defined concept of parliamentarism.

\section{Empirical Starting Points}

The authors of the historically oriented chapters of Part I (Chapters 1 to 7) analyse the concepts of parliament and parliamentarism on the basis of the political debate that has surrounded and taken place within parliaments. In most of these chapters, parliamentary debates themselves - side by side with other primary texts commenting on parliaments and secondary literature - have been used for reconstructing a variety of past experiences and conceptions of the institution. Some authors have been able to proceed to the analysis of a more multisited discourse on parliaments, but this has depended on the availability of digitized parliamentary and press sources in each national case. The chapters are meant to provide surveys of the current state of research and to illustrate the main trends in the history of parliamentarisms by means of a few representative examples. They test the potential of conceptual history for future parliamentary history; more extensive empirical analyses have been or will be presented elsewhere.

What distinguishes the approaches of the chapters of Part I from the other parts is that they are based on empirical historical research and written primarily by historians. The chapters build on traditional historical research on parliaments as institutions, although they also address questions that are of interest to linguists and political theorists as well; this is a result of the effect of the linguistic and discursive turns in the human sciences and of an awareness of ongoing theoretical debates on parliamentarism. The different parts of this work thus proceed from empirical research on parliamentary history to analyses of parliamentary discourse and finally to political theories of parliamentarism. 
While the parliamentary concepts of sovereignty, responsibility, representation and deliberation have been the starting points for research for the chapters, other important concepts contributing to parliamentarisms - such as publicity - have emerged in the process of research on national parliaments. The authors have discussed these concepts insofar as they have turned out to be relevant for particular national cases. Whereas sovereignty, representation and responsibility have already been discussed to some extent in previous research on constitutional history, focusing on deliberation has given rise to some interesting findings that link the parts of this volume.

The authors were asked to concentrate their analyses on debates concerning more controversial, disputed aspects of parliamentary concepts rather than produce a more traditional constitutional history of the structures, practical functioning or rituals of parliaments, even though previous studies on such themes provide invaluable contexts for the more debate-focused analyses provided here. As far as the history of parliamentary events is concerned, only basic information with direct contextual relevance has been provided. By focusing on the often disputed nature of parliament and parliamentarism, we wish to provide fresh perspectives for future parliamentary and conceptual history. The discursive character of parliamentary processes has not previously been emphasized so much in parliamentary history - even though oratory and debate have traditionally been understood as lying at the heart of parliaments as institutions (see Part II). As far as conceptual history is concerned, we argue that it could be developed into a concrete multidisciplinarity realized in cooperation with discourse studies and political science, and developed towards genuinely international comparisons and the analysis of transnational processes of cross-cultural transfers as well as hindrances to such transfers.

In the rest of this introduction, the focus will not only be on general trends in European parliamentary history but also on transnational debates and transfers, and 
transitions and translations of parliamentary concepts between various national contexts. Discussing the shared and divergent features of various European parliamentarisms on a more abstract and generalizing level may reveal alternative forms of development, challenge national historiographies and demonstrate that the national cases are perhaps not quite so unique and self-evident as has been presumed.

\section{Long-term Trends of European Parliamentarisms}

The themes uniting most national histories of parliamentarism that deserve attention include: (i) the timing and the central conceptual changes of the transition from early modern estates representing particular interests and based on an imperative mandate, to the representation of the people by sovereign parliaments with a free mandate; (ii) the timing and major conceptual transformations involved in the transition from the notion of the duality of government and parliament to parliamentary democracy based on governmental responsibility to parliament; (iii) the transnational significance of the competing key models of European parliamentarism; and (iv) the relationship between parliamentary deliberation and publicity. I shall next briefly discuss each of these features, drawing on chapters throughout the book but mainly in Part I.

The Timing and Central Conceptual Features of the Transition from Early Modern Estates to the Parliamentary Representation of the People

Owing to its medieval roots and the need to adapt itself to changing historical contexts, the English parliament had to address several key issues of parliamentary government earlier than most other European representative institutions (see Chapter 9). British parliamentary government in the seventeenth and eighteenth centuries was characterized by continuity and a very gradual change in the key concepts that defined it. The notions of the sovereignty and the representation of the people in Parliament remained disputed and ambiguous but tended 
nevertheless to be increasingly seen as essential features of the institution. While the implementation of parliamentary representation gave rise to questions and suspicion among the public throughout the period, the notion of Parliament as the representative of the people gained ground among parliamentarians from the 1640s onwards, and again in the demands of the reformists after the 1770s. The notion of the accountability of ministers to Parliament also gradually strengthened in the course of the eighteenth century; the 1740s and the 1780s being turning points towards increasingly recognized accountability. And by the 1770 s, deliberation had become a further key concept defining the essence of Parliament (Chapter 2).

Since the French Revolution, impulses towards parliamentary government on the European continent have increasingly originated from France; Britain was sometimes seen as a hypothetical model country for criticisms of domestic circumstances but the political culture was rarely regarded as directly applicable to continental countries. The French National Assembly, on the other hand, was not at first called a parliament, and even though prohibited in 1789, the imperative mandate was reintroduced in the spirit of direct democracy in 1793 and remained a possibility in French theoretical debate until the late nineteenth century. Suffrage and thereby representation were widened considerably in France in 1848, but the duality of government was maintained by establishing first a balancing presidency and later an imperial throne (Chapter 3).

The French and the British parliamentary systems became major objects of comparison for German states in the course of the nineteenth century, starting from southern Germany. However, early nineteenth-century German parliaments tended to be characterized by a continuation of the practices of the early modern estate assemblies. Until 1919 and even in the Weimar Republic, the German political system - and many political cultures in the north of Europe - was characterized by the duality of government and parliament, albeit with an emphasis on the executive. The significance of parliamentary assemblies was based on 
extended representation thanks to the early introduction of universal male suffrage and also on the increase of publicity after 1848. Parliaments were forums for public debate, albeit ones limited by the strong anti-parliamentary tendencies of the Prussian political culture. Even after the parliamentarization and further democratization of the German political system as a consequence of the First World War, the dualism of the political system and antiparliamentary public discourse survived (Chapter 4).

In Scandinavia, two divergent political traditions coexisted: the Swedish-Finnish model, built on an evolution of early modern traditions of representative government, and Danish absolutism, after the fall of which traditions of representative government needed to be constructed in Norway after 1814 and in Denmark after 1849. Until increasing British and French influences took effect in the late nineteenth century, there was a tendency to avoid calling the national representative institution a parliament. The traditional German model of the duality of government and parliament remained dominant in Sweden until 1919 and also in Finland in the republican constitution after 1919 (Chapter 6).

If notions of representation, parliamentarism and democracy have been effectively nationalized and redefined somewhere, that is certainly the case in Russia. The limited influence of the early twentieth-century imperial Duma was further diminished by the strongly anti-parliamentary views of the Bolshevik revolutionaries, who rejected parliaments as bourgeois institutions. The political role of the new Duma since the 1990s is likewise defined in ways that tend to decrease its parliamentary dimensions in any Western European sense and emphasize a characteristically Russian notion of a national parliament (Chapter 7).

\section{The Transition to Parliamentary Democracy}

While the duality of political power in a mixed government has remained a central principle in the British constitution as well, the supremacy of Parliament in relation to the monarchy 
has become stronger since the late seventeenth century and was rarely questioned after the 1770s (Chapter 2). British nineteenth-century parliamentary history was characterized by a gradual extension of representation and ministerial responsibility, despite simultaneous antiparliamentary tendencies. British government was parliamentarized in the aftermath of the Reform of 1832 (Chapter 9), but the real democratization of Parliament took place only as a result of the concentration of parliamentary sovereignty in the Commons with the Parliament Act of 1911 and the introduction of universal suffrage with the Representation of the People Act of 1918.

In the French Third Republic, an extensive parliamentary government based on governmental responsibility was established in 1875; parliamentarism was so extensive that the French system became a typical object of anti-parliamentary criticism (Chapter 3). In the Netherlands, the notion of the sovereignty of the people had, following the French revolutionary model, been included in the constitution of the Batavian Republic, and the National Assembly replaced the early modern Estates General in the late 1790s, but no effective parliamentary sovereignty developed during this short-lived experiment. Later Dutch constitutions and parliamentarians rather emphasized continuity with the old Dutch Republic, never explicitly referred to popular sovereignty and remained suspicious of democracy and the word 'parliament' as well - despite the gradual democratization and parliamentarization of the Dutch polity after around 1900. In Belgium, where the French influence was stronger, the sovereignty of the people was already presented as the supreme authority in the constitution of 1831. Ministerial responsibility was adopted in Belgium in this instrument, earlier than in any other written constitution. Belgian electoral practices and active ‘parliamentary’ life (explicitly so called) provided innovative models for other European parliaments, especially at the turn of the nineteenth and twentieth centuries (Chapter 5). 
In German theoretical and everyday political discourse, it remained difficult if not impossible to reconcile democracy and parliamentarism successfully until the founding of the Federal Republic. Parliamentarism was viewed as a Western export that was inapplicable to Germany. German socialist thinkers saw parliamentarism as having merely an instrumental value, a view that was influential in much of Northern Europe (Chapter 16). Nevertheless, in most countries Social Democrats adopted a more parliamentary strategy in the aftermath of the First World War, evidently as a reaction to the Russian Revolution.

In Scandinavia, Norway was an unexpected forerunner in the introduction of parliamentary government in 1884, challenging the Swedish system with which it was in union until 1905. Denmark followed in 1901, and Finland and Sweden in 1917. Until that time the duality of government with its limitations on parliamentary power was strong and overshadowed radical suffrage reforms such as those that were enacted in Finland in 1906, introducing a unicameral parliament and universal suffrage including women (Chapter 6).

\section{The Westminster Model}

While England had plenty of interaction with the Continent throughout the early modern period, conceptions of English exceptionalism survived and were strengthened after the Reformation. From the seventeenth century onwards, as a result of repeated confrontations between the monarchy and Parliament (see Chapter 9), which led to regicide and the declaration of a republic, the English political system, too, was increasingly seen as distinct from all continental versions. The English/British parliament was viewed as a unique institution hardly comparable with any other, and, consequently, comparisons between it and the estate assemblies in Sweden or Poland, for instance, were also rare in the eighteenth century and usually only provided warning examples serving the purposes of a particular argument (Ihalainen 2010). In later times, too, the use of transnational models in Britain has 
tended to be tactical rather than genuinely enthusiastic (Ihalainen 2014). French representative institutions after the Revolution, for instance, provided a point of comparison against which the British deliberative assembly could be defined. This differs distinctly from the role of the British parliament as an object of comparison - though rarely of direct imitation - on the continent. Many continental reformists were inspired by certain procedural features of Britain’s parliamentary government and its lively parliamentary political culture as an idealized object of comparison, but they, too, tended to view Britain as exceptional.

\section{The French Model}

In continental Europe, the impact of the French model of parliamentary assemblies became considerable after the French Revolution. This impact was not based merely on the obvious cultural (and until 1814 political) dominance of France in many countries but also on the sheer availability of a wide variety of alternative constitutional settlements in France. After the less radical phase of the Revolution, the French parliamentary system began to adopt selected ideas from Britain, including the introduction of bicameralism in 1795 and calls for ministerial responsibility and an emphasis on deliberation after 1815. At the same time, the French model continued to be a trailblazer in reforms such as broadening representation through universal male suffrage and providing remuneration for parliamentarians in 1848. In its republican phases, French parliamentary development was also open to American influences (Chapter 3).

The French model inspired the introduction of representative government in many Italian states in the early nineteenth century, which resulted in brief experiments with parliamentary government in 1849, and the gradual extension of parliamentary power in relation to royal government in the late nineteenth century. Even more than in France, Italian parliamentarism remained an object of criticism, seen as an import from Britain and France 
rather than a result of a national evolution (Chapter 15). Likewise, in early nineteenth-century Spain, many opponents of parliamentary procedures and a new system of representation and ministerial responsibility saw them as being of British or French rather than of national origin; nevertheless, many features of modern parliamentarism were adopted there (Chapter 17). In both Italy and Spain, parliamentary democracies would need to be constructed on a new basis after twentieth-century experiences of fascism.

\section{The Belgian and Norwegian Models}

After the late nineteenth century, the Belgian parliamentary model evoked interest among reformers in several European countries, including Romania in 1866 (Chapter 12). According to Marnix Beyen, it was typical of parliamentary discourse everywhere to question rather than to emphasize the importance of foreign precedents and to appeal to (constructed) national traditions of representative government. Those who applied the Belgian model, for instance, might disregard its emphasis on the notion of popular sovereignty (Beyen 2013). Some of the seemingly transnational character of parliamentary discourse may, indeed, be misleading: parliaments provide parliamentarians of other countries with examples that serve their argument in particular domestic debates or that offer a practical model that is applicable to different national circumstances, but such borrowing does not necessarily constitute a transfer between political cultures.

Among the alternative models, that of the Norwegian constitution of 1814, which concentrated legislative powers in a unicameral parliament, should also be mentioned, even though it only had noteworthy impact on the reform debates in the neighbouring Scandinavian countries in the nineteenth and early twentieth centuries (Chapter 6). 
In Britain, there had been attempts to publish newspaper reports on parliamentary proceedings in the early eighteenth century, but the real breakthrough in parliamentary publicity took place after the 1770 s - despite the continued desire of many MPs to protect the parliamentary privileges of secrecy. However, the views of the British political elite changed quite rapidly by comparison with their European counterparts, and Parliament came to be seen as a centre of political debate that was accountable to the public (Chapter 2; Ihalainen 2013b). In France, the first breakthrough of publicity coincided with the declaration of the sovereignty of the people by the National Constituent Assembly. In the nineteenth century, a further extension took place with an increase in the number of public hearings in the 1860s (Chapter 3) and the intensification of parliamentary reporting (Chapter 10). In late nineteenth-century Italy, too, theorists emphasized the need to connect parliamentary representation with increased publicity (Chapter 15).

In Germany, secrecy was dominant in parliamentary debates until the Frankfurt Parliament of 1848. In imperial Germany, the Reichstag, despite its limited powers, played the role of a major forum of public debate, and this media publicity became more extensive in the Weimar Republic, though it tended to lead to disappointment with, rather than respect for, parliament (Chapter 5). In the Netherlands, the publicity of parliamentary proceedings was introduced with the Batavian Republic, but the parliament remained a forum for an educated elite in the nineteenth century and did not become a popular institution among the population at large (Chapter 4). All in all, most Western European models of parliamentarism witnessed an extension of parliamentary representation and the connected growth of critical parliamentary publicity between the late eighteenth and early twentieth centuries. The relationship between parliaments and publicity remains symbiotic yet also characterized by constant tension. 
Pasi Ihalainen, Ph.D., is Professor of General History, especially comparative early modern and modern European history, at the University of Jyväskylä, Finland. He has studied the secularization of the concept of the political party, the modernization of national identities, the redefinition of democracy in constitutional debates in parliaments, and parliamentary conflict resolution in the long eighteenth century, early twentieth century and contemporary history, often in a comparative north-west European perspective. He is a member of the Board of Directors of the research network EuParl.net.

\section{References}

Beyen, M. 2013. Comment in the EuParl.net Conference, The Hague, 1 June 2013.

Halonen, M., P. Ihalainen and T. Saarinen. 2014. 'Diverse Discourses in Time and Space:

Historical, Discourse Analytical and Ethnographic Approaches to Multi-sited Language

Policy Discourse', in M. Halonen, P. Ihalainen and T. Saarinen, Language Policies in

Finland and Sweden: Interdisciplinary and Multi-sited Comparison. Bristol: Multilingual Matters, pp. 3-28.

Haupt, H.-G. and J. Kocka. 2004. ‘Comparative History: Methods, Aims, Problems’, in D.

Cohen and M. O’Connor (eds), Comparison and History: Europe in Cross-National

Perspective. New York and London: Routledge, pp. 23-39.

Ihalainen, P. 2010. Agents of the People: Democracy and Popular Sovereignty in British and Swedish Parliamentary and Public Debates, 1734-1800. Leiden: Brill Academic Publishers. Ihalainen, P. 2013a. 'Vertaileva Euroopan Historian Tutkimus Parlamenttihistorian Näkökulmasta’, Tieteessä tapahtuu 31(4): 30-35. 
. 2013b. 'Parlamentsdebatten und der Aufstieg Ausserparlamentarischer Medien im

Späten 18. Jahrhundert. Schweden, Grossbritannien und die Niederlande’, in J. Feuchter and

J. Helmrath, Parlamentarische Kulturen vom Mittelalter bis in die Moderne: Reden - Räume

- Bilder. Düsseldorf: Droste Verlag, pp. 97-113.

. 2014. 'Prospects for Parliamentary Government in an Era of War and Revolution:

Britain and Germany in Spring 1917’, in K. Palonen, J.M. Rosales and T. Turkka (eds), The

Politics of Dissensus: Parliament in Debate. Santander: Cantabria University Press and

McGraw Hill, pp. 423-48.

Ihalainen, P. and T. Saarinen. 2014. 'Construing "Language” in Language Policy Discourse:

Finnish and Swedish Legislative Processes in the 2000s', in M. Halonen, P. Ihalainen and T.

Saarinen, Language Policies in Finland and Sweden: Interdisciplinary and Multi-sited

Comparison. Bristol: Multilingual Matters, pp. 29-56.

Skinner, Q. 2002. Visions of Politics, vol. I. Regarding Method. Cambridge: Cambridge

University Press.

Velde, H. te. 2006. 'Political Transfer: An Introduction', European Review of History 12(2): 205-21. 